\title{
Petf Performance Indicator: An Analysis Of Current Tactical Trends In Women's Tennis
}

\author{
Enrico Serfiotis
}

\section{ABSTRACT}

Many studies have focused on isolated tactical characteristics of tennis and have given less importance to the female game. The goal of this article was to create, based on the existing literature and the observation on the women's game, the PETF indicator (Pattern success of women 's tennis), which tries to gather the most important tactical needs of the women's game, and to validate them through questionnaires answered by active players from the WTA circuit and ITF World Tour, seeking to achieve a consensus on the key aspects and analyse their tactical knowledge.
Key words: Tactical, female, training, PETF.

Received: 20 July 2020

Accepted: 20 September 2020 Corresponding author: Enrico Serfiotis, Brazil. Email: enrivasco@hotmail.com

\section{INTRODUCTION}

Advances in sports technology and science have helped female players to be increasingly faster and stronger. However, this does not mean that just the power of the shot is a factor that determines the success in the women's game. Nowadays, aggressive groundstrokes are an integral and essential part of a good player and should be the basis of their tactical pattern, but the use of high bouncing shots, drop shots and approaches to the net cannot be forgotten (Antoun, 2007). And despite sharing these and other characteristics with men's tennis, we know that women's tennis has its peculiarities. Besides highlighting the relevance of the style of play and the tactical patterns, it is important to know how these are created and developed. The need to promote this development from an early age is extremely essential so that, over time, trained patterns of play become habits, trust is established and a personal style is defined. Any pattern of play desired to be mastered in later ages must be worked on in early periods, due to the fact that with just the variation it is not enough. The female game is progressing through a period in which the variation of game plays and patterns has been gaining a considerable importance. However, did that importance come to stay? Or will it be solved with more and more power to the point that they will become less frequent again?

PETF

The PETF indicator was created to highlight and establish criteria for a possible optimal tactical pattern of performance in the women's game. Below are the 11 tactical factors that make up the PETF:
- Stances and aggressive shots

- $\quad$ Serve +1 st aggressive shot

- Serve: power, direction and spin

- Aggressive return near the baseline

- Opening angles with the groundstrokes

- Taking the initiative: by power and variation of rhythm, time and spin

- Powerful change of direction

- Dominate and play with the zones of the court

- Mastering the baseline - net zone transition

- Gain ground and seek to impact the ball on the rise

- Know how to finish off the point from both sides 
The study sought to tactically evaluate professional female players by a questionnaire that had 11 questions, 9 discursive and 2 objective. Most of the questions were as open as possible to check if their answers matched the criteria proposed by the indicator and to analyse their tactical knowledge, therefore, there was no criteria limit to answer them, and the analysis was based on a general trend. The sample was composed by 13 answered questionnaires, 12 of them from WTA ranked players, and one with ITF World Tour ranking. Four countries were represented as follows: 6 Brazilian, 5 Spanish, 1 Mexican and 1 Argentine. The WTA and ITF rankings World Tour of the players ranged 261 and 956 WTA, and 834 of the ITF World Tour. Of the 13 players two were left-handed and the other 11 were right-handed.

Table 1. Questions 1 to 11 of the questionnaire.

\begin{tabular}{|l|l|}
\hline 1 & $\begin{array}{l}\text { Mention the 5 more important tactical factors of the } \\
\text { women's game in your opinion }\end{array}$ \\
\hline 2 & Usually, how is your tactical pattern when serving? \\
\hline 3 & Usually, how is your tactical pattern when receiving? \\
\hline 4 & $\begin{array}{l}\text { Which was the relevance of tactics when you were a } \\
\text { young player and how was it developed? }\end{array}$ \\
\hline 5 & $\begin{array}{l}\text { Which are the changes you make in your game } \\
\text { depending on the court surface? }\end{array}$ \\
\hline 6 & $\begin{array}{l}\text { Do you think that powerfully changing the direction of } \\
\text { the shot is a key aspect of the women's game? }\end{array}$ \\
\hline 8 & $\begin{array}{l}\text { Do you think that a good and quick transition from } \\
\text { defensive to offensive situations is a key aspect of the } \\
\text { women's game? }\end{array}$ \\
\hline 9 & $\begin{array}{l}\text { According to your characteristics, how do you value the } \\
\text { use of the baseline to net transition? }\end{array}$ \\
\hline 10 & $\begin{array}{l}\text { According to your characteristics, how do you value the } \\
\text { use of the variations? }\end{array}$ \\
\hline 11 & $\begin{array}{l}\text { During a point, do you generally look to finish it off with } \\
\text { both sides or do you preferably use more one side than } \\
\text { the other? If possible, justify your answer }\end{array}$ \\
\hline $\begin{array}{l}\text { Indicate if you reflect about the main tactical } \\
\text { characteristics of the women's game nowadays }\end{array}$ \\
\hline
\end{tabular}

RESULTS

A considerable uniformity was found in the 13 completed questionnaires: However, some of the players answered thinking in a strategic mindset about how to establish their plans, while others focused more on tactical solutions that they use more often. The first and last questions were asked on purpose to check whether the answer to the questions matched with what they found determinant for the success of the women's game and they were the questions more open of the questionnaire. Questions from 2 to 5 and from 8 to 10 were also discursive, but dealt about a specific type of play. Questions 6 and 7 were objective and only an option could be chosen. Table 2 shows the answers to each question in decreasing order and the criteria that achieved the same number of votes in the same line. Figure 1 shows the percentage of objective questions.

\begin{tabular}{|c|c|}
\hline Question 1 & Question 8 \\
\hline $\begin{array}{l}\text { Open the court / Solid game } \\
\text { patterns / }\end{array}$ & $\begin{array}{l}\text { Impression of trying to go for it: } \\
12 \text { votes }\end{array}$ \\
\hline $\begin{array}{l}\text { Reading and decision making / } \\
\text { Variations: } 6 \text { votes }\end{array}$ & $\begin{array}{l}\text { Taking advantage of short balls: } 7 \\
\text { votes }\end{array}$ \\
\hline $\begin{array}{l}\text { How to play in important points: } \\
4 \text { votes }\end{array}$ & $\begin{array}{l}\text { When has perceived that the } \\
\text { court is open: } 4 \text { votes }\end{array}$ \\
\hline $\begin{array}{l}\text { Have a plan A and B / change } \\
\text { directions / Opponent's } \\
\text { weaknesses / Reduce the time / } \\
\text { Approach the net: } 3 \text { votes }\end{array}$ & $\begin{array}{l}\text { Perceived the importance and } \\
\text { now it is used more: } 3 \text { votes }\end{array}$ \\
\hline $\begin{array}{l}\text { Know your weapons / Margin: } 2 \\
\text { votes }\end{array}$ & $\begin{array}{l}\text { Know the importance and } \\
\text { acknowledges that should use it } \\
\text { more: } 1 \text { vote }\end{array}$ \\
\hline $\begin{array}{l}\text { Down the line backhand / 1st } \\
\text { serve percentage / good 1st shot } \\
\text { / volume / inside out forehand / } \\
\text { return inside of the court: } 1 \text { vote }\end{array}$ & Question 9 \\
\hline Question 2 & Used and it is key to vary: 10 votes \\
\hline $\begin{array}{l}\text { Take the initiative with serve }+1 \text { st } \\
\text { shot (variation and opening the } \\
\text { court): } 10 \text { votes }\end{array}$ & Used but not specified: 7 votes \\
\hline 1st serve percentage: 3 votes & Mentioned effect: 4 votes \\
\hline $\begin{array}{l}\text { Serve to avoid the opponent to } \\
\text { have space: } 1 \text { vote }\end{array}$ & Mentioned rhythm: 4 votes \\
\hline $\begin{array}{l}\text { Depending on the opponent's } \\
\text { strengths: } 1 \text { vote }\end{array}$ & Mentioned height: 4 votes \\
\hline Question 3 & $\begin{array}{l}\text { Does not use but recognised its } \\
\text { importance: } 1 \text { vote }\end{array}$ \\
\hline $\begin{array}{l}\text { Open the court with the } 2 \text { nd } \\
\text { serve aggressively: } 10 \text { points }\end{array}$ & Question 10 \\
\hline Hitting hard with margin: 7 votes & Preferably forehand: 9 votes \\
\hline Question 4 & Comfortable with both: 8 votes \\
\hline $\begin{array}{l}\text { No relevant in the development } \\
\text { (after maturation): } 8 \text { votes }\end{array}$ & Preferably backhand: 3 votes \\
\hline $\begin{array}{l}\text { From early stages but without } \\
\text { specification: } 5 \text { votes }\end{array}$ & Question 11 \\
\hline Question 5 & $\begin{array}{l}\text { Approaching the net / aggressive } \\
\text { / variation: } 4 \text { votes }\end{array}$ \\
\hline Building the point: 9 votes & Versatility/ serve: 3 votes \\
\hline Reducing the time: 6 votes & $\begin{array}{l}\text { Mobility / changing directions: } 2 \\
\text { votes }\end{array}$ \\
\hline Trajectories and effects: 5 votes & $\begin{array}{l}\text { Keep the pattern / order / } \\
\text { confidence / solid: } 1 \text { vote }\end{array}$ \\
\hline Mobility: 4 votes & $\begin{array}{l}\text { Have a plan A and B / return / } \\
\text { choices / angles: } 1 \text { vote }\end{array}$ \\
\hline Down the line changes: 1 vote & $\begin{array}{l}\text { Effectiveness in the two first balls } \\
\text { / volume / defence: } 1 \text { vote }\end{array}$ \\
\hline Adapting the backswing: 1 vote & \\
\hline $\begin{array}{l}\text { Serving depending on the } \\
\text { conditions: } 1 \text { vote }\end{array}$ & \\
\hline Check the type of ball: 1 vote & \\
\hline
\end{tabular}

Table 2. Answers from the questions. 

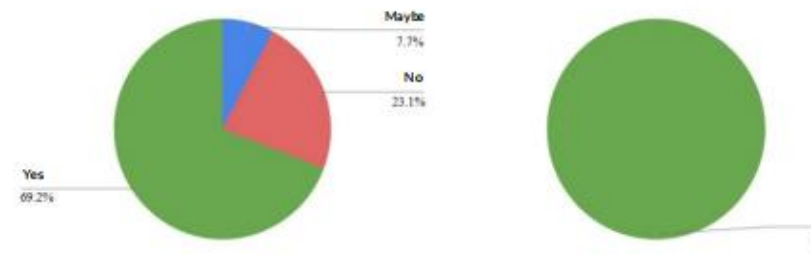

Figure 1. Graphics that refer to questions 6 and 7, respectively.

\section{DISCUSSION}

The answers of the players initially allow to think of two aspects: first, if their perceptions match to that established in the PETF and they are in the right path; second, if they do not correspond with the PETF which implies that they need to adapt to it, or that they are on the right track and there are more important things not included in this context. It is important to emphasise that the purpose of this study was not trying to achieve that all players play always the same, in fact, it has been the opposite. Once identified the relevance of individually considering on all these aspects included in the PETF, both the coach and the player should decide how to work them during practice and use them during match play depending on the set goals. However, it is necessary that all tactical aspects that are defined both inside and outside of the PETF should be worked from the formative phases using, among other tools, the concepts of tactical periodization (Crespo, 2011). This is due to the fact that the majority of the players that answered this questionnaire mentioned that they started their tactical training after their maduration, which is already a late stage.

No player answered the questions so that a defensive behaviour could be understood, on the contrary. All respondents agreed in that they take the initiative, attack and worked the point with an attacking sequence of shots, which is in line with MartinezGallego et to al. (2013; 2018). In addition to that being very positive, a factor already mentioned by Van Aken (2002) is that using a defensive style of play is outdated, aspect that it is true in today's women's elite game. Therefore, it should be remembered that being successful at winning the point is not a matter of power, but in a rally of powerful groundstrokes, variation may be the solution. This attacking pattern was also evident in service and return situations. In this case it is important to emphasise that, although women have less ability to produce powerful strokes than men, they have the potential to develop a powerful service if it is trained at younger ages. In addition, almost all players recognised the importance of variation in the serve and groundstroke game situations, both in the open questions and the specific one. Therefore, power and variation have a fundamental role. It seems that there is no one better than the other, but that they should be efficiently used depending on the game pattern and style of the player (Rodriguez, 2012).

The return of serve is an issue frequently discussed in women's tennis. Its importance is justified due to the fact that female players do not serve as hard and with the same effect as their male counterparts. However, it is true that these characteristics of the serve are more evident in the female game due to the general lack of relevance given to the serve in the development phases. Furthermore, according to Sanchez-Alcaraz Martínez et al. (2018) in the return of serve game situation women win more points than men. Therefore, the return of serve is still a very important game situation in the women's game. However, even though players in the sample did not make any specific comments in the open questions, they could have included it within some of the mentioned features. A positive aspect is that, in the specific question about the game patterns with the return of serve, the majority of the players agreed in that they had an attacking behaviour and liked to take the initiative.

Taking the initiative was mentioned in all answers from the players with great emphasis. This characteristic was identified as a priority for their game together with building the point more on slow courts, opening the court, being aggressive and using variety. These priorities are indicated according to the responses to the factual questions which again showed the intention of being aggressive, the importance of gaining space moving forward and the search for remaining in the offensive zones of the court. An interesting aspect is that players indicated that they hit flatter shots when changing directions and, due to the fact that they have less muscular power than men, a good option to take advantage of the offensive zones of the court and moving to the net could be the reduction of the time by performing a more lineal stroke movement.

Closing points at the net is a game pattern that cannot be forgotten in women's tennis. Players answered that they recognised its importance and that they tried to use this pattern. Therefore, the essential aspect is that this is a habitual game play in which players have confidence in.

On another side, the importance of the backhand in the female game is also discussed, but most of the players indicated that they preferred to dominate and finish the point with their forehands. In this scenario, it seems necessary to reflect if the forehand is really more important than the backhand in the women's game or if the training of the female players is similar to those of their male counterparts.

\section{CONCLUSIONS}

The tactics of the women's game has its peculiarities and needs a specific training system. All the criteria included in the indicator used in this article should be trained with the female players in a tactical development mentality from the formative phases, and should continue to be worked at the professional stage. The baseline-to-net transition was recognised as important by all the players. All of them mentioned that in all of their patterns of play they tried to play offensively and seeking always to take the initiative. Variations were considered important within a game pattern based on an attacking mentality. Therefore, it is necessary to continue observing the different tactical behaviours to evaluate and understand what really happens in the women's professional game. 


\section{REFERENCES}

Antoun, $R$ (2007). Using variety from the baseline in women's tennis. ITF Coaching Sports Science Review 43, 2-3.

Courel-Ibañez, J., García Cambronero, S., Sanchez-Alcaraz Martínez, JB, Sanchez-Pay, A. (2018). Differences in service and return in top 8 men and women ranking. ITF Coaching \& Sport Science Review, 76, 1213.

Crespo, M. (2011). Tactical periodization in tennis: An introduction, ITF Coaching \& Sport Science Review, 53, 16-18.

F. Guzmán, J., James, N., Martínez-Gallego, R., Pers, J., Ramón- Llin, J., Vuckovic, G. (2011). Movement Characteristics of Elite Tennis Players on Hard Courts with Respect to the Direction of Ground Strokes. Journal of Sports Science \& Medicine, 12 (2), 275-281.

Martinez-Gallego, R. (2018). Tactical analysis in tennis: From its origins to the present, ITF Coaching \& Sport Science Review, 74, 23-24.

Rodriguez, C. (2012). Women's tennis: Past, present and future, ITF Coaching \& Sport Science Review, 56, 20-22.

Van Aken, I. (2002). Tactics Specific to the female game, ITF Coaching \& Sport Science Review, 27, 13-14.

RECOMMENDED ITF TENNIS ACADEMY CONTENT (CLICK BELOW)

\section{ITF Academy}

Copyright (c) 2020 Enrico Serfiotis

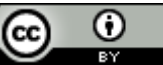

This text is under a Creative Commons BY 4.0 license

You are free to Share - copy and redistribute the material in any medium or format - and Adapt the content - remix, transform, and build upon the material for any purpose, even commercially under the following terms:

Attribution: You must give appropriate credit, provide a link to the license, and indicate if changes were made. You may do so in any reasonable manner, but not in any way that suggests the licensor endorses you or your use.

CCBY4.0 license terms summary $\quad$ CCBY4.0license terms 